\title{
EHMTI-0158. Positive allosteric modulators (PAMS) of the metabotropic glutamate receptor 2 (MGLUR2) are effective against nerve injury induced facial allodynia in rats
}

\author{
${\text { C Horváth }{ }^{1 *}, \text { K Galgóczy }{ }^{1}, \text { K Kordás }^{1} \text {, A Kis-Varga', G Túrós², G Szabó }}^{2}$ \\ From 4th European Headache and Migraine Trust International Congress: EHMTIC 2014 \\ Copenhagen, Denmark. 18-21 September 2014
}

Activation of mGluR2 is known to induce analgesic effect in animal pain models. mGluRs have been found in trigeminal ganglia and dura of rats.

Our aim was to examine effect of mGlu2 PAMS in facial allodynia model induced by partial ligation of infraorbital nerve (pIONL) in rats.

The two selective mGlu2 PAM compounds studied, JNJ-40068782 (JNJ), and Compound A (CA) of G.Richter have high in vitro potency with functional EC50 values on human mGlu2R of $8 \mathrm{nM}$ and $39 \mathrm{nM}$, respectively.

Allodynia was measured by von Frey filaments at least ten days after pIONL. Gabapentin, a drug used in neuropathic pain, and sumatriptan, an anti-migraine drug significantly reduced allodynia.

Single p.o. dosing of CA produced dose-dependent reversal of allodynia with ED50 $=1.7 \mathrm{mg} / \mathrm{kg}$ and maximum effect of $92 \%$ at $10 \mathrm{mg} / \mathrm{kg}$ dose. In a 7-day repeated dose study with $0.5 \mathrm{mg} / \mathrm{kg}$ dose, a sustained, significant effect was seen. Similarly, no sign of tolerance was seen with 10 -day repeated administration of JNJ at $30 \mathrm{mg} / \mathrm{kg}$ p.o. dose, selected based on acute dose-response study.

Potential side effects of both compounds were monitored by an automated behavioral observation system. In the above examined dose range and dosing regimens (acute and chronic) no considerable side effects were detected. No effect of CA on thermal or mechanical nociceptive threshold was seen up to $10 \mathrm{mg} / \mathrm{kg}$ dose.

Our results suggest potential utility of mGluR2 PAMs against trigeminal neuralgia or migraine. CA proved to

'Pharmacological and Drug Safety Research, Gedeon Richter Plc., Budapest, Hungary

Full list of author information is available at the end of the article be similarly effective but much more potent in vivo than JNJ.

\section{Authors' details}

${ }^{1}$ Pharmacological and Drug Safety Research, Gedeon Richter Plc., Budapest, Hungary. ${ }^{2}$ Medicinal Chemistry II., Gedeon Richter Plc., Budapest, Hungary.

Published: 18 September 2014

doi:10.1186/1129-2377-15-S1-F9

Cite this article as: Horváth et al:: EHMTI-0158. Positive allosteric modulators (PAMS) of the metabotropic glutamate receptor 2

(MGLUR2) are effective against nerve injury induced facial allodynia in rats. The Journal of Headache and Pain 2014 15(Suppl 1):F9.

\section{SpringerOpen ${ }^{\circ}$}

๑ 2014 Horváth et al; licensee Springer. This is an Open Access article distributed under the terms of the Creative Commons Attribution License (http://creativecommons.org/licenses/by/2.0), which permits unrestricted use, distribution, and reproduction in any medium, provided the original work is properly cited.
Submit your manuscript to a SpringerOpen ${ }^{\circ}$ journal and benefit from:

- Convenient online submission

- Rigorous peer review

- Immediate publication on acceptance

- Open access: articles freely available online

- High visibility within the field

- Retaining the copyright to your article

Submit your next manuscript at $\boldsymbol{~ s p r i n g e r o p e n . c o m ~}$ 